\title{
Metode Diskusi dalam Meningkatkan Hasil Belajar Pendidikan Agama Kristen pada Peserta Didik Kelas IV Sekolah Dasar
}

\author{
Rinto Hasiholan Hutapea ${ }^{1 *}$ Yuliana Hau Dima \\ ${ }^{1}$ Institut Agama Kristen Negeri Kupang \\ ${ }^{2}$ Alumni Institut Agama Kristen Negeri Kupang \\ *rintohutapea81@gmail.com
}

\begin{abstract}
This study aims to study the benefits of using the discussion method in improving student learning outcomes in Christian Religious Education subjects. This research uses classroom action research. The subjects of this study were a teacher and grade IV students of SD GMIT Oenaek Kabupaten Kupang. The results of the study can be studied in the first cycle and second cycle. In the first cycle students learning outcomes were obtained with an average grade of 72,12 out of 19 students. Of the 19 students, there were 11 people in the completed category, and 8 people in the not completed category. In the implementations of the second cycle of action obtained an average grade of 76,05 from 19 students. Students who participated 19 people, there are 17 people who are categorized as completed, and 2 people who are categorized as not completed. The results of monitoring cycle I and cycle II showed significant changes to the learning outcomes of students. Changes in learning using discussion methods in Christian Religious Education learning have improved the learning methods of students in class IV SD GMIT Oenaek Kabupaten Kupang.
\end{abstract}

Keywords: discussion methods, learning outcomes, students

\begin{abstract}
Abstrak: Penelitian ini bertujuan untuk mengetahui manfaat dari penggunaan metode diskusi dalam meningkatkan hasil belajar peserta didik pada mata pelajaran Pendidikan Agama Kristen. Penelitian ini menggunakan pendekatan Penelitian Tindakan Kelas. Subyek penelitian ini adalah seorang guru dan peserta didik kelas IV SD GMIT Oenaek Kabupaten Kupang. Hasil penelitian dapat digambarkan pada pelaksanaan siklus I dan siklus II. Pada siklus I diperoleh keterangan hasil belajar peserta didik dengan nilai rata-rata kelas adalah 72,12 dari 19 orang peserta didik. Dari 19 orang peserta didik tersebut, terdapat 11 orang yang masuk kategori Tuntas, dan 8 orang yang masuk kategori Belum Tuntas. Pada pelaksanaan tindakan siklus II diperoleh keterangan nilai rata-rata kelas adalah 76,05 dari 19 orang peserta didik. Peserta didik yang berjumlah 19 orang tersebut, terdapat 17 orang yang masuk kategori Tuntas, dan 2 orang yang masuk kategori Belum Tuntas. Hasil observasi siklus I dan siklus II menunjukkan perubahan yang signifikan atas pencapaian hasil belajar peserta didik. Perubahan ini menunjukkan bahwa penggunaan metode diskusi dalam pembelajaran PAK telah dapat meningkatkan hasil belajar peserta didik di kelas IV SD GMIT Oenaek Kabupaten Kupang.
\end{abstract}

Kata Kunci: metode diskusi, hasil belajar, peserta didik

Article History :

Received: 26-05-2020

Revised: 15-06-2020

Accepted: 15-06-2020 


\section{Pendahuluan}

Penelitian ini mengkaji penggunaan metode diskusi dalam upaya meningkatkan hasil belajar Pendidikan Agama Kristen (PAK) di kelas IV SD GMIT Oenaek, Kabupaten Kupang. Tanggung jawab seorang guru PAK di sekolah tidaklah mudah. Terlebih dalam menghadapi fenomena mata pelajaran PAK kurang diminati oleh peserta didik dibanding mata pelajaran lainnya. Tidak jarang kalau fenomena tersebut berdampak pada hasil belajar peserta didik dalam mata pelajaran PAK. Menanggapi persoalan ini, salah satu upaya yang dilakukan oleh seorang guru PAK adalah melakukan variasi metode pembelajaran di kelas. Dalam penelitian ini, salah satu metode pembelajaran yang ingin didalami adalah metode diskusi.

Terkait metode diskusi, masih terdapat persoalan dimana guru PAK masih jarang menggunakannya dalam proses pembelajaran di kelas. Seperti yang diungkapkan oleh Imanuel Agung dan Made Astika. Hasil penelitian yang mereka lakukan menunjukkan bahwa masih dijumpai guru PAK dalam menyampaikan bahan pelajaran dapat dikatakan jarang menggunakan metode diskusi. ${ }^{1}$ Kondisi ini tentu mengkuatirkan sebagai guru PAK.

Menurut B. Suryosubroto, metode diskusi adalah suatu cara penyajian bahan pelajaran di mana guru memberi kesempatan kepada peserta didik (kelompok), untuk mengadakan perbincangan ilmiah guna mengumpulkan pendapat, membuat kesimpulan atau penyusunan berbagai alternatif pemecahan atas sesuatu masalah. ${ }^{2}$ Sementara itu menurut B. S. Sidjabat, metode diskusi ialah metode yang membangun komunikasi dua arah, yaitu terjadinya relasi dan interaksi dialogis antara guru dan peserta didik serta di antara sesama murid. ${ }^{3}$

Kedua pengertian tersebut diperoleh gambaran bahwa metode diskusi dalam pembelajaran di kelas mendorong peserta didik untuk aktif mengeluarkan gagasan dan mencoba untuk memahami materi atau masalah yang disampaikan oleh guru. Dengan pendekatan ini secara tidak langsung dapat meningkatkan minat belajar peserta didik dalam proses pembelajaran. Berkaitan dengan aspek minat ini Bimo Walgito, menegaskan bahwa minat merupakan suatu keadaan dimana seseorang mempunyai perhatian terhadap suatu objek yang sesuai dengan keinginan untuk mengetahui dan mempelajari maupun membuktikannya lebih lanjut serta cenderung untuk lebih aktif terhadap objek tersebut. ${ }^{4}$ Demikian halnya dengan proses pembelajaran PAK di kelas bahwa minat belajar menjadi bagian penting yang perlu ditingkatkan dalam menggunakan metode diskusi.

\footnotetext{
${ }^{1}$ Imanuel Agung dan Made Astika, "Penerapan Metode Mengajar Yesus Menurut Injil Sinoptik dalam Pelaksanaan Pendidikan Agama Kristen di SMA Gamaliel Makassar,"

https://media.neliti.com/media/publications/137520-penerapan-metode-mengajar-yesus-menurut2bc73c0e.pdf.

2 B. Suryosubroto, Proses Belajar Mengajar di Sekolah (Jakarta: Rineka Cipta, 2009), 167.

3 B. S. Sidjabat, Mengajar Secara Profesional (Bandung: Kalam Hidup, 2011), 232.

4 Bimo Walgito, Psikologi Umum (Yogyakarta: Fak. Psikologi UGM, 1997), 38.
} 
Persoalan yang muncul dalam pembelajaran PAK di kelas IV SD GMIT Oenaek Kupang, dapat digambarkan sebagai berikut: pertama, hasil belajar peserta didik dalam aspek kognitif atau penguasaan materi masih belum mencapai Kriteria Ketuntasan Minimum (KKM). Data hasil ulangan mata pelajaran PAK yang dilakukan oleh guru diperoleh nilai rata-rata peserta didik di kelas IV adalah 65 (enam puluh lima). Nilai rata-rata peserta didik ini tentu belum mencapai nilai ketuntansan yang ditetapkan, yaitu 75 (tujuh puluh lima). Masalah kedua yang terjadi ialah masih rendahnya minat dan keaktifan peserta didik dalam proses pembelajaran di kelas. Peserta didik kelas IV belum menunjukkan sikap yang semangat mengikuti pembelajaran PAK. Peserta didik juga enggan untuk mengajukan pertanyaan kepada guru. Peserta didik mengikuti pembelajaran PAK di kelas sekedar memenuhi kewajiban hadir di kelas saja.

Kedua permasalahan di atas, baik masalah masih rendahnya hasil belajar PAK dan rendahnya minat peserta didik merupakan bagian yang saling berkaitan. Minat dan keaktifan peserta didik di kelas memiliki dampak yang besar terhadap hasil belajar. Permasalahan yang dihadapi oleh peserta didik ini tentu perlu diperbaiki. Oleh sebab itu, penelitian ini memiliki tujuan untuk mencoba memberikan solusi atas permasalahan yang terjadi dengan mengimplementasikan secara efektif metode diskusi dalam proses pembelajaran PAK di kelas IV SD GMIT Oenaek Kabupaten Kupang.

\section{Metode Penelitian}

Penelitian ini menggunakan pendekatan Penelitian Tindakan Kelas (PTK). PTK adalah suatu kegiatan penelitian yang berkonteks kelas yang dilaksanakan untuk memecahkan masalah-masalah pembelajaran yang dihadapi oleh guru, memperbaiki mutu dan hasil pembelajaran dan mencobakan hal-hal baru dalam pembelajaran demi peningkatan mutu dan hasil pembelajaran. ${ }^{5}$ Tujuan sederhana dari PTK adalah terkait erat dengan keinginan seseorang untuk meningkatkan dan atau memperbaiki praktek pembelajaran di kelas. ${ }^{6}$

Prosedur yang dilakukan dalam pendekatan PTK yaitu melalui tahapan-tahapan atau sistem siklus. Tahapan siklus dapat dilakukan dengan lebih dari satu siklus. Melalui sistem siklus akan memberikan peluang bagi peneliti untuk menjawab permasalahan yang ditetapkan untuk perbaikan pembelajaran. Setiap siklus terdiri dari empat tahapan yaitu perencanaan, tindakan, observasi, dan refleksi. ${ }^{7}$ Teknik pengumpulan data yaitu

${ }^{5}$ Ani Widayati, “Staf Pengajar Jurusan Pendidikan Akuntansi - Universitas Negeri Yogyakarta 87," JURNAL PENDIDIKAN AKUNTANSI INDONESIA Vol. VI No. 1 - Tahun 2008 Hal. 87 - 93 PENELITIAN VI, no. 1 (2008): 87-93.

${ }^{6}$ Sumini, "Penelitian Tindakan Kelas dan Pengembangan Profesi Guru," Jurnal pendidikan 2, no. 2 (2015): 1-17.

${ }^{7}$ Suharsimi Arikunto, dkk., Penelitian Tindakan Kelas (Jakarta: Bumi Aksara, 2009), 117. 
dengan menggunakan observasi dan dokumentasi. ${ }^{8}$ Observasi adalah metode pengumpulan data melalui pengamatan langsung atau peninjauan secara cermat dan langsung di lapangan atau lokasi penelitian. Teknik ini menggunakan lembar observasi. Sedangkan dokumentasi, yaitu melalui data-data dokumentasi yang tersedia di sekolah yang berkaitan dengan kebutuhan penelitian ini. Data dokumentasi yang dimaksud dalam penelitian ini adalah dokumen nilai peserta didik. Analisis data yang digunakan adalah pendekatan Miles dan Heberman dengan tiga pendekatan, yaitu reduksi data, penyajian data, dan penarikan kesimpulan. ${ }^{9}$ Melalui analisis data hasil PTK ini akan diperoleh hasil dan kesimpulan. Penelitian ini dilakukan selama dua bulan, yaitu bulan Juli dan Agustus pada tahun pelajaran 2017/2018 di kelas IV SD GMIT Oenaek Kupang Barat, Provinsi Nusa Tenggara Timur.

\section{Hasil dan Pembahasan}

\section{Hakikat Metode Diskusi}

Memilih jenis metode mengajar merupakan bagian terpenting yang perlu diketahui oleh guru. Sidjabat menegaskan, pemilihan metode mengajar yang tepat kerap kali harus mempertimbangkan faktor usia dari peserta didik. ${ }^{10}$ Berkaitan dengan itu, Ronald W. Leigh dalam Sidjabat, mendaftarkan sejumlah metode mengajar yang dihubungkan dengan usia peserta didik, dimana metode diskusi kelompok berada pada kelompok usia 6-8 tahun. ${ }^{11}$ Prinsip pemilihan metode ini menjadi bagian penting dalam memahami hakikat dari metode diskusi itu sendiri.

Pembahasan hakekat metode diskusi ini memuat konsep pengertian metode diskusi, langkah-langkah metode diskusi, kelebihan dan kelemahan metode diskusi, serta upaya guru PAK dalam melaksanakan medote diskusi. Pengertian metode diskusi dijabarkan sebagai berikut. Metode berasal dari Bahasa Yunani yaitu methodos yang berarti cara atau jalan yang ditempuh. Sementara diskusi adalah suatu percakapan ilmiah oleh beberapa yang tergabung dalam satu kelompok untuk saling bertukar pendapat tentang sesuatu masalah atau bersama-sama mencari jawaban dan kebenaran atas suatu masalah. ${ }^{12}$ Sementara itu menurut Tukiran Taniredja, dkk menjelaskan diskusi ialah suatu proses penglihatan dua atau lebih individu yang berinteraksi secara verbal dan saling berhadapan muka mengenai tujuan atau sasaran yang sudah ditentukan melalui cara tukar menukar informasi. ${ }^{13}$

${ }^{8}$ Sugiyono, Metode Penelitian Pendidikan: Pendekatan Kuantitatif, Kualitatif Dan R\&D (Bandung: Alfabeta, 2016), 193.

${ }^{9}$ Ibid., 338.

${ }^{10}$ Sidjabat, Mengajar Secara Profesional, 234.

11 Ibid.

${ }^{12}$ Suryosubroto, Proses Belajar Mengajar Di Sekolah. 167.

${ }^{13}$ Tukiran Taniredja, dkk., Model-Model Pembelajaran Inovatif Dan Efektif (Bandung: Alfabeta, 2014), 23. 
Pengertian metode diskusi lainnya dikemukakan oleh Netti Ermi. Ia menjelaskan, metode diskusi ialah suatu cara penyampaian materi pembelajaran dengan jalan bertukar pikiran baik antara guru dengan peserta didik atau peserta didik dengan peserta didik lainnya. Selain itu metode diskusi menumbuhkan motivasi peserta didik untuk berpikir atau mengeluarkan pendapatnya sendiri dengan wawasan pengetahuan yang mampu mencari jawaban. ${ }^{14}$ Dari uraian-uraian pengertian metode diskusi tersebut, dapat disimpulkan bahwa metode diskusi adalah cara yang ditempuh oleh dua atau lebih individu untuk memecahkan suatu masalah. Dalam penelitian ini yang dimaksud dengan memecahkan masalah yaitu masalah hasil belajar peserta didik dalam proses pembelajaran PAK di sekolah.

Pelaksanaan atau implementasi metode diskusi dalam pembelajaran di kelas, ada beberapa langkah yang perlu diperhatikan oleh guru. Suryosubroto menguraikan ada lima langkah dalam metode diskusi. ${ }^{15}$ Kelima langkah tersebut adalah sebagai berikut: pertama, guru mengemukakan masalah yang akan didiskusikan dan memberikan pengarahan seperlunya mengenai cara-cara pemecahannya. Kedua, melalui pimpinan guru, peserta didik membentuk kelompok diskusi (ketua, sekretaris, pelapor), mengatur tempat duduk, ruangan sarana, dan sebagainya. Ketiga, peserta didik berdiskusi di kelompoknya masing-masing sedangkan guru berkeliling dari kelompok satu ke kelompok yang lain untuk menjaga serta memberi dorongan dan bantuan sepenuhnya agar setiap anggota kelompok berpartisipatif aktif supaya diskusi berjalan dengan lancar. Keempat, setiap kelompok diskusi melaporkan hasil diskusinya. Hasilhasil diskusi yang dilaporkan ditanggapi oleh semua siswa (terutama bagi kelompok lain). Guru memberi ulasan dan menjelaskan tahap-tahap laporan-laporan tersebut. Kelima, peserta didik dalam kelompok mencatat hasil diskusi tersebut, guru mengumpulkan hasil diskusi dari tiap-tiap kelompok, sesudah peserta didik mencatat untuk dokumen kelas. Penelitian ini akan mengikuti langkah-langkah metode diskusi ini. Langkah-langkah pelaksanaan metode diskusi tersebut akan diterapkan pada pelaksanaan proses pembelajaran di kelas.

Sementara itu menurut Netti Ermi, ada beberapa tahap pelaksanaan metode diskusi dalam pembelajaran di kelas. Tahapan tersebut adalah:16 (1) Guru menetapkan pokok permasalahan dan peserta didik akan mengemukakan pokok permasalahan yang didiskusikan. (2) Guru menjelaskan tujuan diadakan diskusi. (3) Guru memberikan kesempatan kepada peserta didik dengan bertanya tentang materi yang didiskusikan. (4) Peserta didik melakukan diskusi dengan sesama peserta didik. (5) Peserta didik

\footnotetext{
${ }^{14}$ Netti Ermi, "Penggunaan Metode Diskusi Untuk Meningkatkan Hasil Belajar Materi Perubahan Sosial Pada Siswa Kelas XII SMA Negeri 4 Pekanbaru,” Sorot 10, no. 2 (2015): 155.

15 Suryosubroto, Proses Belajar Mengajar Di Sekolah. 169-170.

${ }^{16}$ Ermi, "Penggunaan Metode Diskusi Untuk Meningkatkan Hasil Belajar Materi Perubahan Sosial Pada Siswa Kelas XII SMA Negeri 4 Pekanbaru.”
} 
menelaah materi yang diajukan guru dan dapat dipahami seluruh peserta diskusi. (6) Peserta didik ikut aktif memikirkan atau mencatat data dari buku-buku sumber pengetahuan lainnya agar dapat mengemukakan jawaban yang benar. Pendapat ini dapat disampaikan dengan pemikiran sendiri maupun pemikiran kelompok. (6) Mendengarkan pendapat dari kelompok lain dan menghargai kelompok yang memberikan pendapat. (7) Mencatat pendapat dari teman-teman dari kelompok lain walaupun jawaban tersebut belum dengan tepat dijawabnya. (8) Menyimpulkan hasil diskusi dari kelompok lain.

Metode diskusi dalam pelaksanaannya memiliki kelebihan dan kelemahan. Adapun kelebihan dari metode diskusi diuraikan oleh Taniredja, dkk sebagai berikut: ${ }^{17}$ pertama, metode diskusi memungkinkan adanya interaksi antara guru dan peserta didik, juga antara peserta didik dengan peserta didik. Kedua, melalui metode diskusi guru dapat membaca pikiran peserta didik tentang konsep yang baru dipelajarinya, seperti menilai pemahaman mereka apakah mereka salah mengerti atau paham terhadap konsep baru tersebut. Selain itu Semiawan dalam Taniredja, dkk mengungkapkan ada tiga kelebihan dari metode diskusi. ${ }^{18}$ Kelebihan dari metode diskusi tersebut adalah: mempertinggi peran serta secara perorangan, mempertinggi peran serta kelas secara keseluruhan, serta memupuk sikap saling menghargai pendapat orang lain.

Metode diskusi juga memiliki kelemahan. Berikut ini beberapa kelemahan dalam metode diskusi menurut Suryosubroto: ${ }^{19}$ pertama, suatu diskusi tidak dapat diramalkan sebelumnya mengenai bagaimana hasil sebab tergantung kepada kepemimpinan peserta didik dan partisipasi anggota-anggotanya. Kedua, suatu diskusi memerlukan keterampilan tertentu yang belum pernah dipelajari sebelumnya. Ketiga, jalannya diskusi dapat dikuasai (didominasi) oleh beberapa peserta didik yang menonjol. Keempat, tidak semua topik dapat dijadikan pokok diskusi, akan tetapi hanya hal-hal yang bersifat problematik saja yang dapat didiskusikan. Kelima, diskusi yang mendalam memerlukan waktu yang banyak. Peserta didik tidak boleh merasa dikejar oleh waktu. Keenam, metode diskusi dibatasi waktu yang dapat menimbulkan kedangkalan dalam diskusi sehingga hasilnya tidak bermanfaat.

Hakikat metode diskusi berikutnya ialah upaya guru PAK dalam melaksanakannya. Guru PAK dalam melaksanakan metode diskusi dalam pembelajaran di kelas, ada beberapa upaya yang perlu diperhatikan. Upaya ini bertujuan agar guru PAK ketika melaksanakan metode diskusi dalam pembelajaran dapat berhasil dengan baik. Pertama ialah pendekatan guru PAK dalam mengaktifkan diskusi kelompok. Pendekatan dalam mengaktifkan diskusi kelompok ini meliputi: ${ }^{20}$ a) Interaksi satu-satu,

17 Taniredja, Model-Model Pembelajaran Inovatif Dan Efektif. 24.

18 Ibid.

${ }^{19}$ Suryosubroto, Proses Belajar Mengajar Di Sekolah. 172.

${ }^{20}$ Sidjabat, Mengajar Secara Profesional, 257-258. 
berarti satu kelompok terdiri atas dua orang. Yesus pernah mengutus murid-murid-Nya dalam kelompok seperti itu (Mrk. 6:7). b) Buzz group, terdiri atas 3-4 orang peserta didik. Diskusi berlangsung beberapa menit, dengan petunjuk atau aba-aba yang jelas, lalu tiap-tiap anggota kembali lagi ke dalam kelompok besar. c) Brainstorming merupakan teknik pengumpulan pendapat atau pengajuan kritik sehingga memperoleh masukan yang tepat untuk mengambil keputusan. Dalam hal ini masalah yang disiskusikan harung diungkapkan dengan jelas, kemudian peserta diberi waktu untuk menuliskan pendapatnya. d) Roleplaying atau permainan peran. Situasi harus jelas, setiap peserta memiliki petunjuk yang jelas tentang perannya. Adalah baik bila ada pengamat yang menilai jalannya permainan peran, kemudian memberikan tanggapan, kesan, dan saran. e) Diskusi penilaian. Kelompok berdiskusi untuk memberi penilaian tentang kegiatan yang telah berlangsung. Masing-masing menuliskan dan mengajukan pendapatnya.

Kedua, upaya yang perlu diperhatikan oleh guru dalam melaksanakan metode diskusi menurut Taniredja, dkk. ${ }^{21}$ Upaya tersebut ialah: 1) Masalah yang diangkat dalam pelaksanaan metode diskusi harus kontroversial, artinya mengandung pertanyaan dari peserta didik. Masalahnya harus menarik perhatian mereka karena bertalian dengan pengalaman mereka. 2) Guru harus menempatkan dirinya sebagai pemimpin diskusi. Ia harus membagikan pertanyaan dan memberi petunjuk tentang jalannya diskusi. Guru juga berperan sebagai penangkis terhadap pertanyaan yang diajukan peserta didik. 3) Guru hendaknya memperhatikan pembicaraan agar fungsi guru sebagai pemimpin diskusi dapat dilaksanakan sebagaimana mestinya. Upaya dan pendekatan ini menjadi bagian penting yang perlu diperhatikan oleh guru PAK dalam pembelajaran di kelas saat menggunakan metode diskusi.

\section{Hasil Belajar}

Pembahasan dalam bagian ini menguraikan konsep hasil belajar. Menurut Abdurrahman dalam buku yang ditulis oleh Asep Jihad dan Abdul Haris, hasil belajar adalah kemampuan yang diperoleh peserta didik setelah melalui kegiatan belajar. ${ }^{22} \mathrm{Di}$ mana belajar itu sendiri merupakan suatu proses dari seseorang yang berusaha untuk memperoleh suatu bentuk perubahan perilaku yang relatif menetap. Sementara itu, menurut Oemar Hamalik, hasil belajar adalah bila seseorang telah belajar akan terjadi perubahan tingkah laku pada orang tersebut, misalnya dari tidak tahu menjadi tahu, dan dari tidak mengerti menjadi mengerti. ${ }^{23}$ Dari aspek PAK, hasil belajar ialah hasil interaksi antara guru dan peserta didik dalam pembelajaran yang mencakup nilai

\footnotetext{
21 Taniredja, Model-Model Pembelajaran Inovatif Dan Efektif. 30.

22 Asep Jihad dan Abdul Haris, Evaluasi Pembelajaran, 14.

23 Oemar Hamalik, Perencanaan Pengajaran Berdasarkan Pendekatan Sistem (Jakarta: Bumi Aksara, 2006), 30.
} 
kebenaran, keadilan, kejujuran, kasih, iman, pengharapan, dan sukacita. ${ }^{24}$ Dari keterangan-keterangan pengertian hasil belajar tersebut, dapat disimpulkan bahwa hasil belajar PAK adalah kemampuan dan perubahan tingkah laku yang diperoleh peserta didik setelah ia melalui proses belajar, yaitu memiliki nilai kebenaran, keadilan, kejujuran, kasih, iman, pengharapan, dan sukacita. Dalam penelitian ini hasil belajar yang dimaksud adalah aspek kognitif atau peguasaan peserta didik dalam bentuk nilai ujian dalam mata pelajaran PAK.

Hasil belajar dapat dipengaruhi oleh beberapa faktor. Ada faktor langsung maupun tidak langsung. Menurut Zainal Arifin, faktor-faktor itu adalah sebagai berikut: ${ }^{25}$ pertama, faktor peserta didik. Faktor peserta didik meliputi kapasitas dasar, bakat khusus, motivasi, minat, kematangan dan kesiapan, sikap dan kebiasaan, dan lainlain. Kedua, faktor sarana dan prasarana. Faktor sarana dan prasarana, baik yang terkait dengan kualitas, kelengkapan maupun penggunaannya, seperti guru, metode dan teknik, media, bahan dan sumber belajar, program, dan lain-lain. Ketiga, faktor lingkungan. Faktor lingkungan baik fisik, sosial maupun kultur, di mana kegiatan pembelajaran dilaksanakan. Kultur masyarakat setempat, hubungan antar insan masyarakat setempat, kondisi fisik lingkungan, hubungan antara peserta didik dengan keluarga, merupakan kondisi lingkungan yang akan mempengaruhi proses dan hasil belajar untuk pencapaian tujuan pembelajaran. Keempat, faktor hasil belajar. Faktor hasil belajar yang merujuk pada rumusan normatif harus menjadi milik peserta didik setelah melaksanakan proses pembelajaran.

Hasil belajar memiliki beberapa ranah/aspek. Menurut teori Benjamin S. Bloom dalam Asep dan Abdul, ada tiga ranah hasil belajar, yaitu kognitif, afektif, dan psikomotorik. $^{26}$ Penjelasannya adalah sebagai berikut: pertama, domain kognitif. Domain kognitif ini mencakup aspek: pengetahuan, pemahaman, apalikasi, analisa, sintesa, dan evaluasi. Kedua, domaian kemampuan sikap (afektif). Domain kemampuan sikap atau afektif ini meliputi aspek: menerima atau memperhatikan, merespon, penghargaan, mengorganisasikan, dan mempribadi (mewatak). Ketiga, ranah psikomotorik. Ranah psikomotorik ini meliputi aspek: menirukan, manipufasi, keseksamaan, artikulasi, dan naturalisasi.

Lebih lanjut, menurut Sudjana dalam buku Asep dan Abdul, ada dua kriteria untuk melihat hasil belajar. ${ }^{27}$ Kriteria itu adalah: pertama, kriteria ditinjau dari sudut prosesnya. Kriteria ini meliputi: (1) Apakah pengajaran direncanakan dan dipersiapkan terlebih dahulu oleh guru dengan melibatkan peserta didik secara sistematik? (2) Apakah kegiatan peserta didik belajar dimotivasi guru sehingga ia melakukan kegiatan

${ }^{24}$ Sidjabat, Mengajar Secara Profesional, 334.

25 Zainal Arifin, Evaluasi Pembelajaran: Prinsip, Teknik, Dan Prosedur (Bandung: Remaja Rosdakarya, 2016), 199-300.

${ }^{26}$ Jihad, Evaluasi Pembelajaran. 16-19.

${ }^{27}$ Ibid. 
belajar dengan penuh kesabaran, kesungguhan dan tanpa paksaan untuk memperoleh tingkat penguasaan, pengetahuan, kemampuan serta sikap yang dikehendaki dari pengajaran itu? (3) Apakah guru memakai multi media? (4) Apakah peserta didik mempunyai kesempatan untuk mengontrol dan menilai sendiri hasil belajar yang dicapainya? (5) Apakah proses pengajaran dapat melibatkan semua peserta didik dalam kelas? (6) Apakah suasana pengajaran atau proses belajar mengajar cukup menyenangkan dan merangsang peserta didik belajar? (7) Apakah kelas memiliki sarana belajar yang cukup kaya, sehingga menjadi laboratorium belajar?

Kedua, kriteria ditinjau dari hasilnya. Kriteria ini meliputi: (a) Apakah hasil belajar yang diperoleh peserta didik dari proses pengajaran nampak dalam bentuk perubahan tingkah laku secara menyeluruh? (b) Apakah hasil belajar yang dicapai peserta didik dari proses pengajaran dapat diaplikasikan dalam kehidupan peserta didik? (c) Apakah hasil belajar yang diperoleh peserta didik tahan lama diingat dan mengendap dalam pikirannya, serta cukup mempengaruhi perilaku dirinya? (d) Apakah yakin bahwa perubahan yang ditunjukkan oleh peserta didik merupakan akibat dari proses pengajaran?

Berkaitan dengan kriteria hasil belajar di atas, maka penulis menyimpulkan bahwa kriteria hasil belajar mencakup: pertama, guru berhasil melaksanakan pembelajaran sesuai dengan perencanaan pembelajaran yang telah dibuat. Kedua, peserta didik dapat mengikuti proses pembelajaran dengan baik. Ketiga, peserta didik mengalami perubahan nilai dan tingkah laku yang lebih baik.

\section{Hakikat PAK}

Pada bagian ini akan dibahas hakikat dari PAK. Hakikat PAK ini meliputi pengertian dan tujuan dari PAK itu sendiri. Menurut Warner C. Graedorf dalam buku Paulus L. Kristanto, PAK adalah proses pengajaran dan pembelajaran yang berdasarkan Alkitab, berpusat pada Kristus, dan bergantung kepada Roh Kudus, yang membimbing setiap pribadi pada semua tingkat pertumbuhan melalui pengajaran masa kini ke arah pengenalan dan pengalaman rencana dan kehendak Allah melalui Kristus dalam setiap aspek kehidupan, dan melengkapi mereka bagi pelayanan yang efektif, yang berpusat pada Kristus sang Guru Agung dan perintah yang mendewasakan pada murid. ${ }^{28}$ Berikutnya pengertian PAK yang diuraikan oleh Robert R. Boehlke dalam bukunya Sejarah Perkembangan Pemikiran dan Praktek PAK dari Plato sampai Ig. Loyola mengutip pernyataan Martin Luther (1483-1548), yang menjelaskan pengertian PAK. Pengertian PAK adalah pendidikan yang melibatkan warga jemaat untuk belajar teratur dan tertib agar semakin menyadari dosa mereka serta bersukacita dalam firman Yesus Kristus

${ }^{28}$ Paulus Lilik Kristanto, Prinsip Dan Praktek PAK Penuntun Bagi Mahasiswa Teologi Dan PAK, Pelayan Gereja, Guru Agama Dan Keluarga Kristen (Yogyakarta: Andi Offset, 2007), 4. 
yang memerdekakan. ${ }^{29}$ PAK berfungsi untuk memperlengkapi mereka dengan sumber iman, khususnya yang berkaitan dengan pengalaman berdoa, firman dan rupa-rupa kebudayaan sehingga mereka mampu melayani sesamanya termasuk masyarakat dan negara serta mengambil bagian dengan bertanggung jawab dalam persekutuan Kristen. Berdasarkan pengertian-pengertian tersebut, maka penulis berpendapat bahwa PAK adalah proses pembelajaran yang berlandaskan nilai-nilai kristiani dalam membentuk dan mendidik peserta didik dalam proses pembelajaran di sekolah.

PAK juga memiliki tujuan. Adapun tujuan PAK adalah untuk mengajak, membantu, menghantar seseorang untuk mengenal kasih Allah yang nyata dalam Yesus Kristus, sehingga dengan pimpinan Roh Kudus ia datang ke dalam persekutuan yang hidup dengan Tuhan. Hal tersebut dinyatakan dalam kasihnya terhadap Allah dan sesama, yang dihayati dalam hidupnya sehari-hari, baik dengan kata-kata maupun perbuatan selaku anggota tubuh Kristus. ${ }^{30}$ Tujuan PAK ini merupakan bagian penting yang perlu diperhatikan oleh guru dalam proses pembelajaran di kelas.

Pengertian dan tujuan PAK di atas merupakan sasaran yang ingin dicapai oleh guru PAK dalam pembelajaran di kelas. Salah metode mengajar yang digunakan oleh guru PAK adalah metode diskusi. Metode diskusi dalam PAK ialah suatu pelayanan atau suatu pekerjaan yang aktif yang dilakukan bagi Firman Tuhan dan sesama manusia, supaya kedua pihak bertemu satu sama lain. Artinya, guru PAK memiliki peran yang strategis untuk mencapai tujuan PAK dalam pembelajaran di kelas dengan menggunakan metode diskusi.

\section{Pembahasan}

Penelitian ini menggunakan pendekatan PTK. Tahapan pelaksanaan PTK dalam penelitian ini menggunakan 2 (dua) siklus. Pelaksanaan PTK ini dilakukan oleh peneliti sendiri sebagai guru PAK serta didampingi orang rekan sejawat sebagai penilai dalam mengisi lembar observasi di kelas. Secara singkat, subyek penelitian tindakan ini adalah peserta didik kelas IV SD GMIT Oenaek sebanyak 19 (sembilan belas) orang yang terdiri dari 7 (tujuh) orang laki-laki dan 12 (dua belas) orang perempuan.

Penelitian PTK ini hendak mengetahui dan mendeskripsikan penggunaan metode diskusi terhadap peningkatan hasil belajar peserta didik kelas IV GMIT Oenaek Kupang. Ada beberapa prosedur yang perlu diperhatikan. Berikut prosedur PTK menurut Suharsimi Arikunto, dkk.: ${ }^{31}$ pertama, tahap perencanaan. Pada tahap perencanaan ini guru merencanakan hal-hal yang akan diajarkan serta permasalahan yang ada, dan cara pemecahannya. Adapun hal-hal yang dilakukan dalam pada tahap

${ }^{29}$ Robert R. Boehlke, Sejarah Perkembangan Pikiran Dan Praktek Pendidikan Agama Kristen: Dari Yohanes Amos Comenius Sampai Perkembangan PAK Di Indonesia (Jakarta: BPK Gunung Mulia, 1994), 342. 31.

30 Daniel Nuhamara, Pembimbing Pendidikan Agama Kristen (Bandung: Jurnal Info Media, 2009),

${ }^{31}$ Arikunto, Suharsimi, Penelitian Tindakan Kelas. 117-119. 
perencanaan antara lain: (a) Guru melakukan analisis standar isi untuk mengetahui standar kompetensi dan kompetensi dasar. (b) Penyusunan program pembelajaran sesuai dengan Kompetensi Dasar. (c) Menentukan tempat atau lingkungan sebagai sumber belajar, serta menentukan waktu yang dibutuhkan. (d) Membentuk kelompok belajar. (e) Peneliti menyusun skenario pembelajaran. (f) Peneliti mengundang nara sumber jika dibutuhkan. (g) Peneliti membuat lembar kerja siswa sesuai dengan Kompetensi Dasar. (h) Menyiapkan alat penilain untuk proses pembelajaran dan sejauh mana pemahaman peserta didik setelah melakukan pembelajaran di luar kelas terhadap objek langsung.

Kedua, tahapan pelaksanaan Tindakan. Pada tahapan ini, rancangan strategi dan skenario pembelajaran diterapkan. Skenario tindakan harus dilaksanakan secara benar tampak berlaku wajar. Pelaksanaan tindakan merupakan suatu tindakan yang dilakukan oleh guru atau peneliti sebagai upaya perbaikan atau perubahan yang diinginkan. Peran peneliti pada pelaksanakan tindakan yaitu ikut terlibat dalam proses pembelajaran yang telah direncanakan yaitu sesuai judul yang di angkat.

Ketiga, tahapan observasi (pengamatan). Observasi sebagai alat pengumpulan data yang sistematis artinya teknik observasi secara pencatatannya dilakukan untuk menafsirkan secara ilmiah. Pada tahap observasi ini guru merekam kegiatan peserta didik untuk mendapatkan data-data dari hasil pembelajaran, agar peneliti atau guru mendapatkan hasil yang valid, memilih teman sejawat atau guru lain sebagai observer terhadap tindakan yang dilakukan peneliti sesuai dengan pedoman atau lembar observasi yang telah disiapkan. Dalam observasi ini guru sejawat atau observer mengamati secara langsung tentang: (1) Kesiapan guru dalam hal instrumen pengajaran, materi dan mental peserta didik dalam mengawali pembelajaran. (2) Motivasi peserta didik dalam proses belajar mengajar. (3) Keaktifan peserta dalam pembelajaran. (4) Kemampuan guru dalam menyajikan lingkungan sebagai sumber belajar yang menyenangkan bagi peserta didik. (5) Kemampuan guru dalam mengevaluasi hasil belajar. (6) Kemampuan guru untuk menumbuhkan minat belajar peserta didik. Untuk mendapatkan data tentang kinerja guru, kinerja peserta didik, dan minat belajar peserta didik instrumen yang digunakan yaitu: Lembar Obervasi.

Keempat, tahapan refleksi. Refleksi dimaksudkan untuk mengkaji secara menyeluruh tindakan yang telah dilakukan, berdasarkan data yang telah berkumpul, kemudian dilakukan evaluasi guna untuk menyempurnakan tindakan berikutnya. Pada tahap refleksi ini guru dan observer berupa teman atau guru sejawat mengadakan diskusi untuk menganalisis sekala sikap dari hasil pre test dan post test yang dilakukan peserta didik, dari hasil pengamatan kinerja peserta didik dan guru PAK serta keaktifan peserta didik dalam pembelajaran. Hasil dari refleksi ini oleh guru PAK dijadikan acuan untuk mengadakan perbaikan-perbaikan, dan selanjutnya direncanakan kembali pada 
pelaksanaan siklus II. Apabila pada Siklus I hasil belajar peserta didik belum mencapai target yang telah ditentukan, maka penelitian belum dapat dikatakan berhasil, sehingga peneliti harus melanjutkan ke siklus II. Apabila pada siklus II hasil belajar peserta didik sudah mengalami peningkatan dengan menggunakan langkah-langkah yang benar sesuai dengan target yang telah direncanakan, maka penelitian baru dikatakan berhasil. Pada pelaksanaan siklus I maupun siklus II, peneliti akan menggunakan materi pelajaran yang sama dalam pembelajaran dengan metode diskusi di kelas.

Langkah-langkah pelaksanaan pembelajaran dan penelitian tindakan pada siklus I dan siklus II mengikuti tahapan pada tabel 1 berikut ini:

\section{Tabel 1.}

Tahapan Pembelajaran

I. Kegiatan Awal

1. Guru menyapa siswa dengan salam syalom

2. Guru menanyakan keadaan siswa

3. Guru mengajak siswa bernyanyi "Terimakasih Tuhan" dan berdoa

4. Guru mengabsen siswa

II. Kegiatan Inti

1. Guru menjelaskan secara jelas pokok bahasan tentang Hidup Bergantung kepada Tuhan.

2. Guru menjelaskan prosedur diskusi dengan membahas tokoh Hana dalam 1 Samuel 1:1-24; Kisah Para Rasul 4:24-31.

3. Guru membagi kelompok diskusi menjadi 4 kelompok

4. Siswa tersebar di kelompok diskusi dan melakukan diskusi

5. Presentasi hasil diskusi dari masing-masing kelompok

III. Kegiatan Akhir

1. Guru meminta siswa merefleksikan hasil diskusi

2. Guru menyimpulkan materi pembelajaran dari hasil diskusi

3. Guru memberi tes kecil dari materi pembelajaran

4. Guru menutup dengan bernyanyi dan berdoa

Penilaian:

1. Penilaian lembar pengamatan

2. Penilaian lembar tes siswa

\section{Hasil Siklus I}

Pelaksanaan pembelajaran dengan menggunakan metode diskusi dilaksanakan oleh guru PAK dengan memperhatikan tahapan pembelajaran pada tabel 1. Tema materi pelajaran yang digunakan oleh guru PAK sebagai peneliti pada siklus ini tertera pada 
tabel 1 di atas. Adapun hasil penelitian yang dilakukan oleh guru PAK pada peserta didik kelas IV SD GMIT Oenaek Kabupaten Kupang pada tahapan siklus I adalah sebagai berikut. Hasil tahapan siklus I diperoleh dari hasil pengolahan data. Pengolahan data yang dimaksud adalah hasil penelitian instrumen yang digambarkan dengan skala hasil penilaian observasi dan tes yang dilakukan oleh guru PAK dan peserta didik. Hasil observasi yang dilakukan observer kepada guru PAK tergambar pada tabel 2. Hasilnya diperoleh gambaran sebagai berikut: pertama, tahapan awal pembukaan. Pada tahapan ini aspek salam dan guru menjelaskan pokok bahasan memperoleh penilaian aktif. Artinya, peserta didik memberikan respon yang baik ketika memberikan salam kepada guru serta mendengarkan dengan baik penjelasan pokok bahasan yang diberikan oleh guru PAK. Sementara itu, aspek doa dan menyanyi memperoleh penilaian tidak aktif. Artinya, ketika kegiatan doa dan menyanyi beberapa peserta didik menunjukkan sikap yang kurang baik dan tidak serius.

Kedua, tahapan kegiatan inti. Pada tahapan ini aspek-aspek kegiatan inti umumnya memperoleh penilaian aktif. Artinya, guru sudah baik dalam menjelaskan secara jelas pokok bahasan kepada peserta didik, guru sudah baik dalam menjelaskan prosedur diskusi, guru sudah baik dalam membagi kelompok diskusi, serta peserta didik sudah baik tersebar di kelompok-kelompok diskusi. Ketiga, tahapan kelompok diskusi. Pada tahapan ini kelompok dibagi menjadi 4 bagian. Dari 4 kelompok, ada 2 kelompok yang memperoleh penilaian aktif, yaitu kelompok 2 dan 4, serta ada 2 kelompok yang tidak aktif yaitu kelompok 1 dan 3 . Artinya, kelompok yang memperoleh penilaian aktif melakukan diskusi dengan baik. Sementara kelompok yang memperoleh penilaian tidak aktif melakukan diskusi kurang baik. Dengan kata lain, ada anggota kelompok yang tidak serius mengikuti diskusi dalam kelompok. Keempat, tahapan evaluasi hasil diskusi. Pada tahapan ini aspek yang memperoleh penilaian tidak aktif adalah aspek saling melengkapi. Artinya, masih terdapat anggota kelompok yang tidak berani mengeluarkan pendapat dalam menanggapi hasil diskusi kelompok lain. Sekalipun demikian, guru telah memberikan motivasi dan penguatan kepada masing-masing kelompok.

Tabel 2.

Hasil Observasi Siklus 1

\begin{tabular}{|c|l|c|c|c|}
\hline No & \multicolumn{1}{|c|}{ Aspek Observasi } & \multicolumn{2}{|c|}{ Hasil Observasi } & \multirow{2}{*}{ Ket. } \\
\cline { 3 - 4 } & & Aktif & Tidak Aktif & \\
\hline 1 & Awal Pembukaan: & & & \\
\hline & a. Salam & $\sqrt{ }$ & \\
\hline & b. Doa & & $\sqrt{ }$ & \\
\hline & c. Menyanyi & $\sqrt{ }$ & \\
\hline & $\begin{array}{l}\text { d. Menjelaskan pokok } \\
\text { bahasan }\end{array}$ & & & \\
\hline 2 & Kegiatan Inti: & $\sqrt{ }$ & \\
\hline & $\begin{array}{l}\text { a. Guru menjelaskan secara } \\
\text { jelas pokok bahasan }\end{array}$ & $\sqrt{ }$ & \\
\hline
\end{tabular}




\begin{tabular}{|c|l|c|c|c|}
\hline \multirow{4}{*}{} & b. Guru menjelaskan diskusi & $\sqrt{ }$ & & \\
\hline & $\begin{array}{l}\text { c. Guru membagi kelompok } \\
\text { diskusi }\end{array}$ & $\sqrt{ }$ & & \\
\hline & $\begin{array}{l}\text { d. Siswa tersebar di } \\
\text { kelompok diskusi }\end{array}$ & $\sqrt{ }$ & & \\
\hline \multirow{2}{*}{3} & Kelompok Diskusi: & & & \\
\hline & $\begin{array}{l}\text { a. Kelompok 1 } \\
\text { b. Kelompok 2 }\end{array}$ & $\sqrt{ }$ & & \\
\hline & c. Kelompok 3 & $\sqrt{ }$ & \\
\hline & d. Kelompok 4 & & & \\
\hline \multirow{2}{*}{4} & Hasil Diskusi & & $\sqrt{ }$ & \\
\hline & a. Tahap melengkapi & $\sqrt{ }$ & \\
\hline & $\begin{array}{l}\text { b. Guru memberikan } \\
\text { penguatan }\end{array}$ & & & \\
\hline
\end{tabular}

Berikutnya ialah penilaian hasil belajar peserta didik pada siklus I. Hasil belajar peserta didik kelas IV SD GMIT Oenaek ini, dapat dilihat pada tabel 3 hasil belajar siklus I. Dari tabel tersebut diperoleh keterangan bahwa dari 19 orang peserta didik di kelas IV nilai rata-rata kelas adalah 72,12. Dari 19 peserta didik, terdapat 11 peserta didik yang masuk kategori Tuntas, dan 8 peserta didik yang masuk kategori Belum Tuntas. Dari data ini menunjukkan bahwa jumlah peserta didik yang Belum Tuntas masih cukup besar. Untuk itu, masih perlu dilakukan upaya dan perbaikan yaitu dengan melakukan tahapan lebih lanjut pada siklus II.

Tabel 3.

Hasil Belajar Siklus I

\begin{tabular}{|c|c|c|c|c|}
\hline No & Nama Siswa & Nilai & Tuntas & Belum Tuntas \\
\hline 1 & Siswa 1 & 70 & & $\sqrt{ }$ \\
\hline 2 & Siswa 2 & 70 & & $\sqrt{ }$ \\
\hline 3 & Siswa 3 & 75 & $\sqrt{ }$ & \\
\hline 4 & Siswa 4 & 80 & $\sqrt{ }$ & \\
\hline 5 & Siswa 5 & 75 & $\sqrt{ }$ & $\sqrt{ }$ \\
\hline 6 & Siswa 6 & 60 & & $\sqrt{ }$ \\
\hline 7 & Siswa 7 & 60 & & $\sqrt{ }$ \\
\hline 8 & Siswa 8 & 75 & $\sqrt{ }$ & \\
\hline 9 & Siswa 9 & 70 & & $\sqrt{ }$ \\
\hline 10 & Siswa 10 & 75 & $\sqrt{ }$ & \\
\hline 11 & Siswa 11 & 75 & $\sqrt{ }$ & \\
\hline 12 & Siswa 12 & 80 & $\sqrt{ }$ & \\
\hline 13 & Siswa 13 & 70 & & $\sqrt{ }$ \\
\hline 14 & Siswa 14 & 60 & & \\
\hline 15 & Siswa 15 & 80 & $\sqrt{ }$ & \\
\hline 16 & Siswa 16 & 80 & $\sqrt{ }$ & \\
\hline 17 & Siswa 17 & 75 & $\sqrt{ }$ & \\
\hline
\end{tabular}




\begin{tabular}{|c|c|c|c|c|}
\hline 18 & Siswa 18 & 60 & & $\sqrt{ }$ \\
\hline 19 & Siswa 19 & 80 & $\sqrt{ }$ & \\
\hline \multicolumn{2}{|c|}{ Jumlah } & 1.370 & & \\
\hline Rata-rata & 72,12 & & \\
\hline
\end{tabular}

Keterangan: Batas Nilai Tuntas adalah 75 (Tujuh Puluh Lima)

\section{Hasil Siklus II}

Pelaksanaan siklus II dilakukan oleh guru PAK dengan mengikuti langkahlangkah pembelajaran pada tabel 1 di atas. Pelaksanaan siklus II ini, peneliti masih menggunakan materi yang sama dengan materi yang digunakan pada siklus I. Analisa siklus II ini diperoleh dari hasil pengolahan data pada instrumen penelitian tahapan siklus II. Hasil penelitian instrumen penelitian ini digambarkan dengan skala hasil penilaian observasi dan tes yang dilakukan pada peserta didik kelas IV SD GMIT Oenaek Kupang. Berikut analisa dari instrumen penelitian tersebut. Tahapan siklus II pada tabel 4 observasi guru diperoleh gambaran sebagai berikut: pertama, tahapan awal pembukaan. Pada tahapan ini umumnya aspek-aspek awal pembukaan memperoleh penilaian aktif. Artinya, peserta didik sudah memberikan respon yang baik dalam proses awal pembukaan. Kekurangan pada siklus I sudah diperbaiki, yaitu menyangkut aspek doa dan menyanyi. Kedua aspek ini sudah mendapatkan perhatian serius dari peserta didik.

Kedua, tahapan kegiatan inti. Pada tahapan aspek-aspek kegiatan inti tidak mengalami perubahan. Umumnya memperoleh penilaian aktif. Artinya, guru sudah baik dalam menjelaskan secara jelas pokok bahasan kepada peserta didik, guru sudah baik dalam menjelaskan prosedur diskusi, guru sudah baik dalam membagi kelompok diskusi, serta peserta didik sudah baik tersebar di kelompok-kelompok diskusi. Ketiga, tahapan kelompok diskusi. Pada tahapan ini umumnya sudah memperoleh penilaian aktif. Artinya, semua aspek dalam kelompok sudah berjalan dengan baik. Kekurangan pada siklus I sudah dapat diperbaiki, yaitu kelompok 1 dan 3 sudah mengalami peningkatan dimana anggota kelompok saling bekerja sama dan melakukan diskusi dengan baik. Keempat, tahapan evaluasi hasil diskusi. Pada tahapan ini aspek-aspek sudah dalam kategori penilaian aktif dan sudah baik. Artinya, aspek yang memperoleh penilaian tidak aktif pada siklus I sudah diperbaiki pada siklus II. Aspek itu adalah saling melengkapi. Artinya, masing-masing kelompok sudah dapat memberikan tanggapan atas hasil diskusi kelompok yang lainnya. Demikian juga dengan guru, guru sudah menjalankan perannya dengan baik dengan memberikan bimbingan dan penguatan pada kelompok-kelompok diskusi. 
Tabel 4

Hasil Observasi Siklus II

\begin{tabular}{|c|l|c|c|c|}
\hline \multirow{2}{*}{ No } & \multicolumn{1}{|c|}{ Aspek Observasi } & \multicolumn{2}{c|}{ Hasil Observasi } & \multirow{2}{*}{ Ket. } \\
\hline & & Aktif & Tidak Aktif & \\
\hline 1 & Awal Pembukaan: & & & \\
\hline & a. Salam & $\sqrt{ }$ & & \\
\hline & b. Doa & $\sqrt{ }$ & & \\
\hline & c. Menyanyi & $\sqrt{ }$ & & \\
\hline 2 & d. Menjelaskan pokok bahasan & Kegiatan Inti: & $\sqrt{ }$ & \\
\hline & $\begin{array}{l}\text { a. Guru menjelaskan secara jelas } \\
\text { pokok bahasan }\end{array}$ & $\sqrt{ }$ & & \\
\hline & b. Guru menjelaskan diskusi & $\sqrt{ }$ & & \\
\hline & c. Guru membagi kelompok & $\sqrt{ }$ & \\
\hline & \multicolumn{1}{|c|}{ diskusi } & & & \\
\hline 3 & d. Siswa tersebar di kelompok & $\sqrt{ }$ & & \\
\hline & Kelompok Diskusi: & & & \\
\hline & a. Kelompok 1 & $\sqrt{ }$ & & \\
\hline & b. Kelompok 2 & $\sqrt{ }$ & & \\
\hline & c. Kelompok 3 & $\sqrt{ }$ & & \\
\hline & d. Kelompok 4 & & & \\
\hline & Hasil Diskusi & a. Tahap melengkapi & & \\
\hline & b. Guru memberikan penguatan & $\sqrt{ }$ & \\
\hline
\end{tabular}

Berikutnya ialah penilaian hasil belajar peserta didik pada siklus II. Hasil belajar peserta didik kelas IV SD GMIT Oenaek Kupang ini dapat dilihat pada tabel 5, yaitu tabel hasil belajar siklus II. Dari tabel tersebut diperoleh keterangan bahwa dari 19 orang jumlah peserta didik di kelas IV nilai rata-rata kelas adalah 76,05. Dari 19 peserta didik, terdapat 17 peserta didik yang masuk kategori Tuntas, dan 2 peserta didik yang masuk kategori Belum Tuntas. Data ini menunjukkan bahwa jumlah peserta didik yang Belum Tuntas mengalami penurunan yang cukup besar, sebaliknya jumlah peserta didik yang Tuntas mengalami peningkatan.

Tabel 5

Hasil Belajar Siklus II

\begin{tabular}{|c|c|c|c|c|}
\hline No & Nama Siswa & Nilai & Tuntas & Belum Tuntas \\
\hline 1 & Siswa 1 & 75 & $\sqrt{ }$ & \\
\hline 2 & Siswa 2 & 75 & $\sqrt{ }$ & \\
\hline 3 & Siswa 3 & 80 & $\sqrt{ }$ & \\
\hline 4 & Siswa 4 & 85 & $\sqrt{ }$ & \\
\hline
\end{tabular}




\begin{tabular}{|c|c|c|c|c|}
\hline 5 & Siswa 5 & 75 & $\sqrt{ }$ & \\
\hline 6 & Siswa 6 & 70 & & $\sqrt{ }$ \\
\hline 7 & Siswa 7 & 75 & $\sqrt{ }$ & \\
\hline 8 & Siswa 8 & 75 & $\sqrt{ }$ & \\
\hline 9 & Siswa 9 & 75 & $\sqrt{ }$ & \\
\hline 10 & Siswa 10 & 75 & $\sqrt{ }$ & \\
\hline 11 & Siswa 11 & 75 & $\sqrt{ }$ & \\
\hline 12 & Siswa 12 & 80 & $\sqrt{ }$ & \\
\hline 13 & Siswa 13 & 75 & $\sqrt{ }$ & \\
\hline 14 & Siswa 14 & 65 & & \\
\hline 15 & Siswa 15 & 80 & $\sqrt{ }$ & \\
\hline 16 & Siswa 16 & 80 & $\sqrt{ }$ & \\
\hline 17 & Siswa 17 & 75 & $\sqrt{ }$ & \\
\hline 18 & Siswa 18 & 75 & $\sqrt{ }$ & \\
\hline 19 & Siswa 19 & 80 & $\sqrt{ }$ & \\
\hline \multicolumn{7}{|c|}{ Jumlah } & 1.445 & & \\
\hline \multicolumn{2}{|c|}{ Rata-rata } & 76,05 & & \\
\hline
\end{tabular}

Keterangan: Batas Nilai Tuntas adalah 75 (Tujuh Puluh Lima)

Apabila dibandingkan hasil belajar peserta didik kelas IV SD GMIT Oenaek Kupang pada siklus I dan II, maka hasilnya adalah sebagai berikut: pada siklus I nilai rata-rata kelas adalah 72,12 dan pada siklus II menjadi 76,05 . Jumlah peserta didik yang Tuntas pada siklus I sebanyak 11 orang, sementara pada siklus II berubah menjadi 17 orang. Selanjutnya, jumlah peserta didik yang Belum Tuntas pada siklus I sebanyak 8 orang, sementara pada siklus II menjadi 2 orang. Terjadi perubahan dan peningkatan yang signifikan atas pencapaian hasil belajar peserta didik dalam mata pelajaran PAK ketika guru PAK menggunakan metode diskusi.

Pelaksanaan siklus I dan Siklus II dalam penelitian ini menggunakan materi pelajaran yang sama. Materi dan permasalahan yang diangkat dalam diskusi kelompok sama. Dalam proses diskusi kelompok tersebut, membuat pembahasan semakin dalam dan dipahami oleh peserta didik. Dengan kondisi diskusi yang semakin baik, peserta didik semakin memahami materi pelajaran. Inilah yang membuat perubahan hasil belajar peserta didik dalam pelajaran PAK semakin meningkat.

Hasil belajar yang dicapai peserta didik di atas menunjukkan bahwa metode diskusi sangat efektif digunakan dalam proses pembelajaran di kelas. Hal ini senada dengan penjelasan Semiawan dalam Taniredja, dkk (2014:24), yang menjelaskan betapa bermanfaatnya metode diskusi. Dimana ia mengungkapkan bahwa ada tiga keuntungan metode diskusi, yaitu: ${ }^{32}$ 1) Dapat mempertinggi peran serta secara perorangan, 2)

\footnotetext{
32 Taniredja, Model-Model Pembelajaran Inovatif Dan Efektif. 24.
} 
Dapat mempertinggi peran serta kelas secara keseluruhan, dan 3) Dapat memupuk sikap saling menghargai pendapat orang lain. Hal ini berdampak pada meningkatnya minat peserta didik dalam mengikuti proses pembelajaran PAK di kelas.

Berdasarkan hasil penelitian, penggunaan metode diskusi oleh guru PAK dalam proses pembelajaran dapat berjalan dengan baik dan efektif. Hal ini terlihat jelas dari hasil belajar peserta didik yang mengalami peningkatan. Dari hasil penelitian ini memberikan gambaran bahwa penggunaan metode diskusi dalam pembelajaran di kelas, menuntut guru PAK untuk serius dalam melaksanakannya. Ketidakseriusan guru PAK akan mengakibatkan penggunaan metode diskusi tidak akan berhasil. Terkait ini, guru PAK perlu untuk terus mengembangkan kompetensi atau kemampuan dalam menggunakan metode diskusi dalam pembelajaran di kelas. Untuk itu, pimpinan atau kepala sekolah sekiranya dapat memberikan kesempatan kepada guru-guru PAK untuk mengembangkan diri dengan mengikuti pelatihan-pelatihan. ${ }^{33}$ Pelatihan-pelatihan pembelajaran baik metode atau media pembelajaran penting bagi guru PAK terutama dalam meningkatkan hasil belajar dan dalam mencapai tujuan pembelajaran.

\section{Kesimpulan}

Dari pembahasan dan analisa hasil pengolahan data di atas, diperoleh gambaran bahwa penggunaan metode diskusi dalam meningkatkan hasil belajar peserta didik di kelas IV SD GMIT Oenaek Kupang berhasil dan sangat bermanfaat. Hasil penelitian menunjukkan adanya peningkatan dan perubahan hasil belajar peserta didik dalam mata pelajaran PAK. Peningkatan hasil belajar tersebut dapat dilihat dari tahapan pelaksanaan tindakan kelas siklus I dan siklus II. Pada siklus I diperoleh keterangan hasil belajar peserta didik dengan nilai rata-rata kelas adalah 72,12 dari 19 orang peserta didik. Dari 19 orang peserta didik tersebut, terdapat 11 orang yang masuk kategori Tuntas, dan 8 orang yang masuk kategori Belum Tuntas. Pada pelaksanaan tindakan siklus II diperoleh keterangan nilai rata-rata kelas adalah 76,05 dari 19 orang peserta didik. Peserta didik yang berjumlah 19 orang tersebut, terdapat 17 orang yang masuk kategori Tuntas, dan 2 orang yang masuk kategori Belum Tuntas. Hasil observasi siklus I dan II menunjukkan peningkatan yang signifikan atas pencapaian hasil belajar peserta didik. Perubahan ini menunjukkan bahwa penggunaan metode diskusi dalam pembelajaran PAK telah dapat meningkatkan hasil belajar peserta didik di kelas IV SD GMIT Oenaek Kabupaten Kupang.

Berdasarkan hasil penelitian tersebut, maka peneliti memberikan saran sebagai berikut: pertama, guru PAK perlu mencoba dengan baik penggunaan metode diskusi dalam pembelajaran di kelas-kelas PAK lainnya, khususnya dalam upaya meningkatkan hasil belajar peserta didik. Kedua, peneliti memberikan saran kepada penelitian sejenis

\footnotetext{
${ }^{33}$ Rinto Hasiholan Hutapea, "Instrumen Evaluasi Non-Tes Dalam Penilaian Hasil Belajar Ranah Afektif Dan Psikomotorik," BIA': Jurnal Teologi dan Pendidikan Kristen Kontekstual 2, no. 2 (2019): 151165, http://jurnalbia.com/index.php/bia/article/view/94.
} 
untuk mengembangkan penggunaan metode diskusi untuk jenis metode buzz group, studi kasus, dan jenis metode diskusi lainnya.

\section{Referensi}

Agung, Imanuel dan Made Astika. "Penerapan Metode Mengajar Yesus Menurut Injil Sinoptik dalam Pelaksanaan Pendidikan Agama Kristen di SMA Gamaliel Makassar." https://media.neliti.com/media/publications/137520-penerapanmetode-mengajar-yesus-menurut-2bc73c0e.pdf.

Ani, Widayati. "Staf Pengajar Jurusan Pendidikan Akuntansi - Universitas Negeri Yogyakarta 87." JURNAL PENDIDIKAN AKUNTANSI INDONESIA Vol. VI No. 1 Tahun 2008 Hal. 87 - 93 PENELITIAN VI, no. 1 (2008): 87-93.

Arifin, Zainal. Evaluasi Pembelajaran: Prinsip, Teknik, dan Prosedur. Bandung: Remaja Rosdakarya, 2016.

Arikunto, Suharsimi, dkk. Penelitian Tindakan Kelas. Jakarta: Bumi Aksara, 2009.

Boehlke, Robert R. Sejarah Perkembangan Pikiran Dan Praktek Pendidikan Agama Kristen: Dari Yohanes Amos Comenius Sampai Perkembangan PAK Di Indonesia. Jakarta: BPK Gunung Mulia, 2009.

Ermi, Netti. "Penggunaan Metode Diskusi Untuk Meningkatkan Hasil Belajar Materi Perubahan Sosial Pada Siswa Kelas XII SMA Negeri 4 Pekanbaru." Sorot 10, no. 2 (2015): 155.

Hamalik, Oemar. Perencanaan Pengajaran Berdasarkan Pendekatan Sistem. Jakarta: Bumi Aksara, 2006.

Hutapea, Rinto Hasiholan. "Instrumen Evaluasi Non-Tes Dalam Penilaian Hasil Belajar Ranah Afektif Dan Psikomotorik." BIA': Jurnal Teologi dan Pendidikan Kristen Kontekstual 2, no. 2 (2019): 151-165. http://jurnalbia.com/index.php/bia/article/view/94.

Jihad, Asep dan Abdul Haris. Evaluasi Pembelajaran, 2012.

Kristanto, Paulus Lilik. Prinsip Dan Praktek PAK Penuntun Bagi Mahasiswa Teologi Dan PAK, Pelayan Gereja, Guru Agama Dan Keluarga Kristen. Yogyakarta: Andi Offset, 2007.

Nuhamara, Daniel. Pembimbing Pendidikan Agama Kristen. Bandung: Jurnal Info Media, 2009.

Sidjabat, B. S. Mengajar Secara Profesional. Bandung: Kalam Hidup, 2011.

Sugiyono. Metode Penelitian Pendidikan: Pendekatan Kuantitatif, Kualitatif Dan R\&D. Bandung: Alfabeta, 2016.

Sumini. "Penelitian Tindakan Kelas Dan Pengembangan Profesi Guru." Jurnal pendidikan 2, no. 2 (2015): 1-17.

Suryosubroto, B. Proses Belajar Mengajar Di Sekolah. Jakarta: Rineka Cipta, 2009.

Taniredja, Tukiran dkk. Model-Model Pembelajaran Inovatif Dan Efektif. Bandung: Alfabeta, 2014.

Walgito, Bimo. Psikologi Umum. Yogyakarta: Fak. Psikologi UGM, 1997. 